Several papers dealt with the allied problems of the runt syndrome and homologous disease, and ample evidence is presented to support the thesis that both these phenomena are due to the immunological reaction of foreign cells against a tolerant host. Simonsen and Jensen describe an ingenious graft versus host assay, and Gorer and Boyse suggest that the destruction of host lymphoid cells and tissues may be in the nature of an allergic reaction.

One gains the impression that this symposium was of great interest and benefit to those who participated, since many of the most interesting ideas and speculations were brought out in the addenda and discussions. The editors, organizers and publishers are to be congratulated on the speed of publication (the book was available at the end of last year) although the presentation of the book has suffered thereby. There are several errors in the list of contents and the absence of an index is a marked disadvantage both to the general reader and to those seeking a work of reference. The composition and arrangement of the twenty-nine papers varies considerably ; only eleven had summaries and of the four papers in French only two had summaries in English. The collection of the material under appropriate subject headings would have been advantageous. For example, although the problem of overcoming the practical difficulties inherent in transplantation is considered in some papers the data are not presented in such a way as to be readily accessible to surgeons and others with little time to read all 453 pages.

However, this is a comprehensive volume of papers for workers in this field and the reviews of recent work would be useful for those already familiar with current trends.

D. M. V. Parrott

\section{GENERAL PHYSIOLOGY}

Principles of General Physiology

By W. M. Bayliss. Fifth Edition by Dr. L. E. Bayliss. Vol. 1. Pp. xiii +520 ; Vol. 2. Pp. xxii +848 . (London : Longmans, Green and Co., Ltd., 1959 and 1960.) Vol. 1, 55s. net. Vol. 2, 90s. net.

A Textbook of General Physiology

By Dr. Hugh Davson. Second Edition. Pp. xvi+ $846+32$ plates. (London: J. and A. Churehill, Ltd., 1959.) 84s. net.

TN 1916 appeared the first edition of "Bayliss" and 1 in 1951 that of Davson. Claude Bernard had defined general physiology as "the study of phenomena common to plants and animals". William Bayliss, in the first edition of his "Principles", had adopted Burdon-Sanderson's definition "the study of the endowments of living materials". Dr. Davson indicated that in practice Bayliss restricted this study to those aspects of living material which showed some immediate prospect of being described in terms of the known laws of physies and chemistry.

He referred to the fact that Dr. Leonard E. Bayliss, son of Sir William Bayliss, was preparing a fifth edition of his father's "Principles". Despite the years since it was first written (1916) and since its last edition in 1924, it still led the field. This fifth edition shows changes in format, in ambit and approach, so marked that even the publishers seem uncertain as to the author. On page iii (the title-page) it is described as by L. E. Bayliss ; on page iv as the "Fifth Edition of W. M. Bayliss's Principles by L. E. Bayliss"'. What does it matter? The genetic interrelationship is so close that the initials are almost of no importance. Dr. Leonard Bayliss has had a bigger task, which he has accomplished by scrapping entirely the old book and writing two volumes, one largely on physical chemistry in its own right and a second (entitled "General Physiology") on the applications in living material. In this, he has been singularly successful, for the internal classification within these volumes is a physiological classification based on function and not on morphological systems. This he has illustrated by studying phenomena at all levels in botany, zoology and microbiology. He has some beautiful discussions on the applications of modern physics in even more modern biology, particularly in the chapter on servo-mechanisms.

Dr. Davson's book has three new chapters, on "Sensory Response", on "Excitability of Cardiac Muscle" and on "Electrical Activity in Smooth Muscle". He stresses functional energy in metazoa and particularly in the integrated vertebrate. He is therefore most informing when discussing the underlying biophysics of mammalian physiology. He has also been able to focus on the last decade aspects of cell structure, particularly the work of Watson and Crick in regard to inclusion bodies, nucleo-protein, the cell membrane, protein synthesis and viruses.

General physiology is splitting into biophysics and biochemistry, and biomathematics. The recent finding of polarization in light coming from Mars, suggesting absorption bands reminiscent of carbonhydrogen chains and of cellulose, points to a bioastronomy. The physicist is making serious endeavours to utilize models as an aid to interpretation of the nervous system. Sir Cyril Hinshelwood, in his presidential address to the Royal Society last year, suggested the time is ripe to apply modern scientific disciplines to the study of the paranormal phenomena of extra-sensory perception. The all-in-all book embracing the whole of general physiology is going to be more and more difficult to write and maintain.

These two branches, from the root stem $\mathrm{Sir}$ William Bayliss, are most impressive ; each author has had a. somewhat different task, each has worked differently and each produced a book that is invaluable. What is both interesting and important is that, while different, they integrate and reciprocate with each other and the possession of one is no reason for not possessing the other.

A. Sr. G. HUGGETT

\section{ANALYTICAL CHEMISTRY OF POLYMERS}

Analytical Chemistry of Polymers

Edited by Gordon M. Kline. Part 1: Analysis of Monomers and Polymeric Materials: PlasticsResins-Rubbers-Fibres. (High Polymers : d series of Monographs on the Chemistry, Physies and Technology of High Polymeric Substances, Vol. 12, Part 1.) Pp. xviii +666 . (New York : Interscience Publishers, Inc.; London: Interscience Publishers, Ltd., 1959.) 125s.

YNDUSTRIALLY, the term high-polymers covers I vinyl plastics, condensation polymers-important in the synthesis of fibres, resins and drying oilsnatural and synthetic rubbers, proteins, ion-exchange 